Guest Editorial, part of a Special Feature on Catastrophic Thresholds, Perspectives, Definitions, and Applications

\title{
Introduction to Special Feature on Catastrophic Thresholds, Perspectives, Definitions, and Applications
}

\author{
$\underline{\text { Robert A. Washington-Allen }}^{1}, \underline{\text { David D. Briske }}^{1}, \underline{\text { Herman H. Shugart }}^{2}$, and Lucinda F. Salo $^{3}$
}

\begin{abstract}
The contributions to this special feature focus on several conceptual and operational applications for understanding non-linear behavior of complex systems with various ecological criteria at unique levels of organization. The organizing theme of the feature emphasizes alternative stable states or regimes and intervening thresholds that possess great relevance to ecology and natural resource management. The authors within this special feature address the conceptual models of catastrophe theory, selforganization, cross-scale interactions and time-scale calculus; develop operational definitions and procedures for understanding the occurrence of dynamic regimes or multiple stable states and thresholds; suggest diagnostics tools for detection of states and thresholds and contribute to the development of scaling laws; and finally, demonstrate applications that promote both greater ecological understanding and management prescriptions for insect and disease outbreaks, resource island formation, and characterization of ecological resilience. This Special Feature concludes with a synthesis of the commonalities and disparities of concepts and interpretations among the contributed papers to identify issues and approaches that merit further research emphasis.
\end{abstract}

Key Words: catastrophe theory; complex systems science; dynamical systems analysis; ecological resilience; non-equilibrium ecology; self-organization; thresholds; time-scale calculus

\section{INTRODUCTION}

A symposium titled: "Catastrophic Thresholds, Perspectives, Definitions, and Applications" was organized for the 2006 Ecological Society of America's (ESA) 91st Annual Meeting in Memphis, Tennessee titled: "Icons and Upstarts in Ecology" with support from the Rangeland Ecology Section of ESA (Washington-Allen and Salo 2007). Catastrophic thresholds are of tremendous relevance to ecology and ecosystem management because they signify the occurrence of substantial and potentially irreversible change that may variously affect patterns and processes, including their capacity to provision services upon which human societies depend (Gunderson 2000, Scheffer and Carpenter 2003). Although thresholds have attracted a great deal of both theoretical and empirical attention, numerous questions remain regarding their significance and interpretation (Briske et al. 2006, Groffman et al. 2006). The papers presented in this special issue represent contributions from both symposium speakers and other scientists to address thresholds within the context of the complex behavior of both terrestrial and aquatic systems.

Threshold behavior of ecosystem pattern and process in space and time was initially conceptualized by C. S. Holling (1973) in his landmark paper introducing resilience. Thresholds can be defined in time and space by numerous synonyms including ecotones, borders, regime shifts, discontinuities or non-linearities, phase transitions, points of criticality, and tipping points between two or more dynamic regimes or alternative states (Fig. 1, Mayer and Rietkerk 2004). Thresholds can emphasize various ecological attributes or ecological criteria at unique levels of organization, e.g., communities or ecosystems (Allen and Hoesktra 1992, Beisner et al. 2003). Adjectives that have been used with threshold include transition (Archer 1989), critical, and catastrophic (Scheffer et al. 2001). The artist M. C. Escher has provided many works that are iconic metaphors for pattern and process, including his 1956 wood engraving "Swans" where flying black

\footnotetext{
${ }^{1}$ Department of Ecosystem Science and Management, Texas A\&M University, ${ }^{2}$ W.W. Corcoran Professor of Environmental Sciences \& Director, Center for
} Regional Environmental Studies, Department of Environmental Sciences, University of Virginia, ${ }^{3}$ Sage Ecosystem Science 
swans rapidly change into white swans in a chiral Möbius strip (http://www.mcescher.com/). Contemporary research has renewed emphasis on catastrophic thresholds, primarily by the application of catastrophe theory (Thom 1972, Gilmore 1981, Lockwood and Lockwood 1993, Washington-Allen et al. 2006), self-organized criticality (Bak et al. 1987, Olsen et al. 2005, Pascual and Guichard 2005), and time scale or invariant calculus (Hilger 1990, Thomas and Urena 2001) as conceptual frameworks for operational use in natural resource management.

\section{Concepts and Approaches}

Marten Scheffer, the overview speaker for the ESA symposium and author of the recent book "Critical Transitions" (Scheffer 2009), discussed the use of catastrophe theory as a conceptual framework for understanding gradual and abrupt behavior in both terrestrial and aquatic ecosystems (Scheffer 2009). Lockwood and Lockwood (2008, this feature) use both catastrophe theory and self-organized criticality to describe and explain the pattern and process of grasshopper population outbreaks in the western United States. Similarly, Ridolfi et al. (2008, this feature) elaborate on the roles of shrub encroachment and soil erosion on the emergence of "fertility island" pattern formation at the landscape spatial scale in drylands (Schlesinger et al. 1990, Jackson and Caldwell 1993). They applied a non-linear diffusion model of shrub encroachment limited by erosiondriven loss of soil resources to simulate the development, multiple states, and spatial patterns of islands of fertility within landscapes.

Thomas et al. (2009, this feature) introduce a new perspective for modeling ecological phenomena by presenting one of the first applications of time-scale calculus (TSC, Hilger 1990) to simulate the impact of West Nile virus on human, mosquito, and bird populations in New York City, New York. Their findings provide a critical contribution to informing city managers with recommendations for management of mosquito populations (Thomas and Urena 2001, Thomas et al. 2009). TSC is based on unification of the relationship between difference equations, which are used to model discrete behavior, and differential equations, which are used to model continuous behavior. Consequently, it can be used to model systems that exhibit both continuous and discrete behavior (Hilger 1990, Bohner and Peterson 2001).

Garmestani et al. (2009, this feature) evaluate empirical evidence of discontinuous distributions within complex systems to disentangle the occurrence of emergent properties, including resilience. Panarchy theory indicates that complex systems exhibit multiple dynamic regimes nested within larger systems, each of which operate at unique scales. The authors used analysis of discontinuities to reveal panarchy and interpret pattern in ecological as well as urban and social systems to further explain how resilience is generated.

Allen and Holling (2010, this feature) describe the concept of novelty within complex systems that emphasizes changes in key drivers and selforganizing interactions to maintain resilience or establish it when resilience of a stable state has been lost. They hypothesize that novelty will most likely be expressed near shifts or breaks in scale where large fluctuations in resource variability increase the success of random events to affect system reorganization. Novel events are assumed to have limited opportunity for success far from scale shifts because constant patterns of resource availability are fully exploited.

\section{Definitions}

Ecological Society of America (ESA) symposium speaker Dr. Tamzen Stringham of the University of Nevada-Reno discussed the concepts of multiple stable states and regime shifts to the real-world challenge of describing vegetation and soil dynamics of drylands (Washington-Allen and Salo 2007). Previously, the ecological basis of land management models assumed predominately linear ecosystem dynamics that were primarily endogenously driven (an equilibrium view; Westoby et al. 1989). However, a number of federal agencies have recently adopted non-equilibrium ecological concepts for ecosystem assessment in the form of state-and-transition models that can accommodate non-linear ecosystem dynamics and the formation of alternative stable states (Westoby et al. 1989). Consequently, Stringham provided contemporary definitions for process-based state-and-transition models (Westoby et al. 1989, Bestlemeyer et al. 2003, Stringham et al. 2003, Briske et al. 2005) that have direct application to ecosystem management.

\section{Diagnostic Detection Tools}

Scheffer (2009) and Scheffer et al. (2009) discussed the use of diagnostic tools from time-series analysis for detecting threshold events, including spectral 
Fig. 1. Two- (a) and three-dimensional (b) representation of threshold dynamics and regime shifts in time and space. Shifts from regime 1 to regime 3 have been measured as an increase or decrease in mean and variance of vegetation (and soil) response (a, Washington-Allen et al. 2006, 2008, and 2009). Regime shifts translate to three dimensions with the addition of drivers that induce either discrete (A through D) or continuous ( $\mathrm{E}$ and $\mathrm{F}$ ) change in response variables (b).
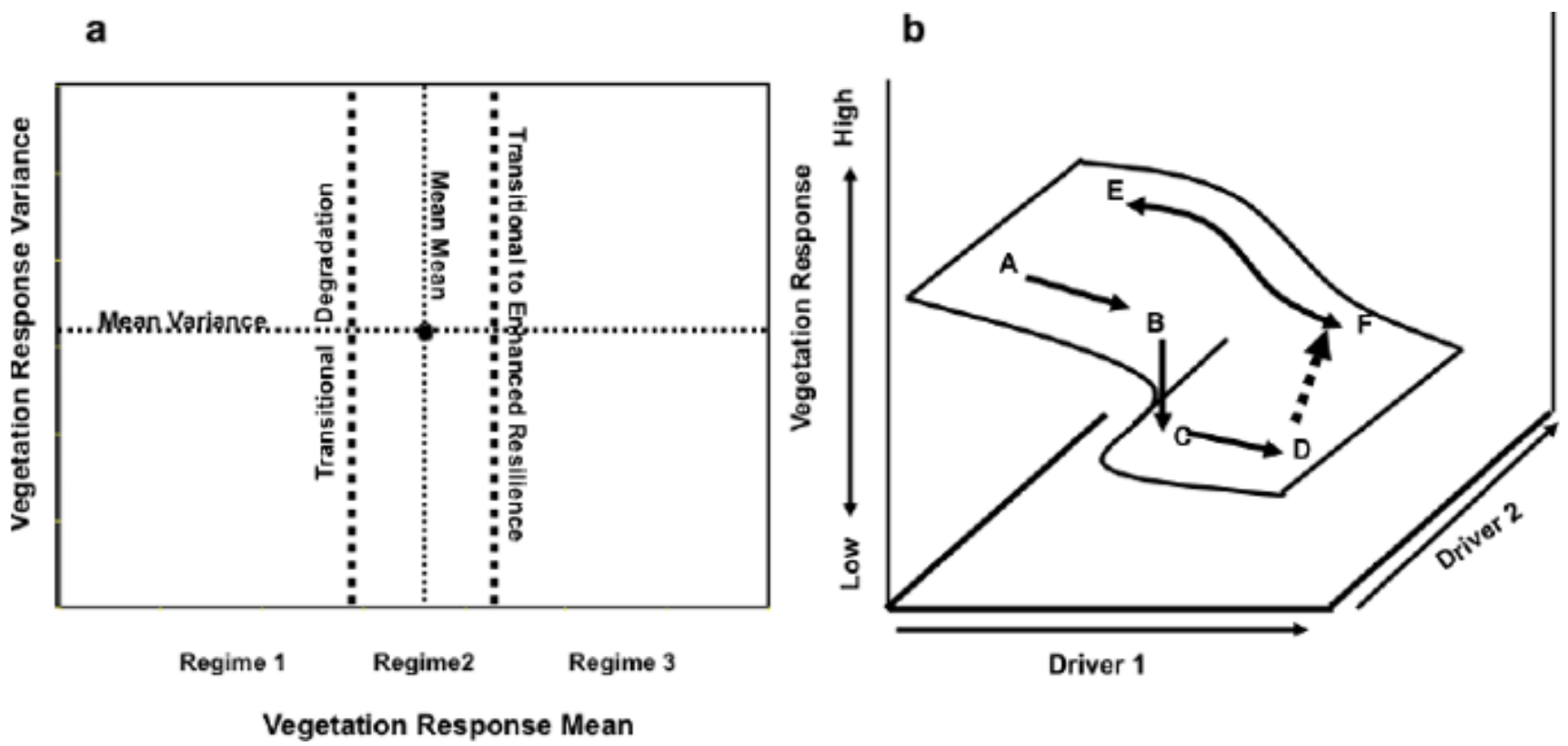

analysis for red shifts, sudden jumps in time, increases in parameter variance, and divergence. Similarly, Washington-Allen et al. (2008, this feature) demonstrated the use of a digital change detection method: time-series image differencing and dynamical systems analysis to retrospectively provide measures of ecological resilience in response to droughts and the land-management practices of agropastoralists.

Johnson (2009, this feature) and Wardwell and Allen (2009, this feature) show that increases in the spatial and temporal variance in various attributes of aquatic and terrestrial ecosystems, respectively, can be used to detect scale breaks or thresholds (e.g., Habeeb et al. 2005, 2007). Johnson (2009, this feature) shows that the use of space-for-time substitution, as an alternative to rarely available or difficult-to-collect long-time series, allows for the first time detection of the characteristic or natural length scales (CLS) of different communities. CLS is a measure of the change in magnitude of the prediction error as the scale of observation of species abundance (e.g., measured as percent cover) changes (Habeeb et al. 2005). Determination of CLS allows the definition of the optimum scale for monitoring, interpreting change in ecological dynamics and defining independent or complex interactions between different species.

Wardwell and Allen (2009, this feature) observed that discontinuous structures at different spatial scales result in discontinuities between aggregated species' body-mass patterns, reflecting the scales of structure available to animal communities within a landscape. This has led to a textural discontinuity hypothesis that predicts that variability in population abundance is greater in animal species near the edge of body-mass aggregations than it is in species in the interior of body-mass aggregations. Garmenstani et al. (2009, this feature) have expanded this concept beyond ecological systems to broader application to social systems as panarchy.

\section{CONCLUSIONS}

Table 1 summarizes the topics, level of organization, and methods for detecting state and thresholds that the authors in this special feature will present. Briske et al. (2010, this feature) provide a synthesis of the concepts and applications presented in the symposium and contributed papers to 
Table 1. Authors contributing to this special feature, their research purpose or question, the level of organization, interactions, study location, and major method of analysis.

\begin{tabular}{|c|c|c|c|c|c|}
\hline Author & Research Question/Purpose & $\begin{array}{l}\text { Level of } \\
\text { Organization }\end{array}$ & Interaction & Study Location & $\begin{array}{l}\text { Method of } \\
\text { Analysis }\end{array}$ \\
\hline $\begin{array}{l}\text { Washington-Allen } \\
\text { et al. }\end{array}$ & $\begin{array}{l}\text { Which plant communities } \\
\text { are resilient in the face of } \\
\text { drought? }\end{array}$ & Landscape & $\begin{array}{l}\text { Vegetation and } \\
\text { drought }\end{array}$ & Dryland & $\begin{array}{l}\text { Image } \\
\text { differencing }\end{array}$ \\
\hline $\begin{array}{l}\text { Wardwell and } \\
\text { Allen }\end{array}$ & $\begin{array}{l}\text { Are discontinuities in } \\
\text { landscapes associated with } \\
\text { discontinuities in body mass } \\
\text { aggregations? }\end{array}$ & $\begin{array}{l}\text { Community- } \\
\text { Landscape }\end{array}$ & $\begin{array}{l}\text { Birds and } \\
\text { environmental } \\
\text { gradients }\end{array}$ & Wetland & $\begin{array}{l}\text { Textural } \\
\text { discontinuity } \\
\text { hypothesis, } \\
\text { spatial analysis } \\
\text { of variance }\end{array}$ \\
\hline Johnson & $\begin{array}{l}\text { To determine the optimum } \\
\text { scale for monitoring } \\
\text { community dynamics. }\end{array}$ & Community & Marine organisms & Marine/tropical & $\begin{array}{l}\text { Celluar } \\
\text { automata, space- } \\
\text { for-time } \\
\text { substitution, } \\
\text { prediction- }{ }^{2} \text { and } \\
\text { error-x analyses }\end{array}$ \\
\hline Allen and Holling & $\begin{array}{l}\text { How does novelty } \\
\text { contribute to system } \\
\text { resilience? }\end{array}$ & Multiple & $\begin{array}{l}\text { Cross-scale } \\
\text { Cross-levels }\end{array}$ & Multiple & Panarchy theory \\
\hline Garmestani et al. & $\begin{array}{l}\text { Do system discontinuities } \\
\text { function as drivers of } \\
\text { regime shifts and resilience? }\end{array}$ & $\begin{array}{l}\text { Social and } \\
\text { ecological } \\
\text { systems }\end{array}$ & $\begin{array}{l}\text { Cross-scale } \\
\text { Cross-levels }\end{array}$ & Multiple & $\begin{array}{l}\text { Analysis of } \\
\text { discontinuities } \\
\text { in space and } \\
\text { time }\end{array}$ \\
\hline Thomas et al. & $\begin{array}{l}\text { How do you mathematically } \\
\text { describe both discrete and } \\
\text { continuous population } \\
\text { dynamics in the interactions } \\
\text { among four different } \\
\text { species? }\end{array}$ & Community & $\begin{array}{l}\text { Mosquitoes, } \\
\text { virus, humans, } \\
\text { and birds }\end{array}$ & Urban/Tropics & $\begin{array}{l}\text { Time-scale } \\
\text { calculus model }\end{array}$ \\
\hline Ridolfi et al. & $\begin{array}{l}\text { How do patterns of islands } \\
\text { of fertility emerge at the } \\
\text { landscape level? }\end{array}$ & Landscape & $\begin{array}{l}\text { Soil erosion and } \\
\text { vegetation } \\
\text { encroachment }\end{array}$ & Dryland & $\begin{array}{l}\text { Non-linear } \\
\text { spatial diffusion } \\
\text { simulation } \\
\text { model }\end{array}$ \\
\hline $\begin{array}{l}\text { Lockwood and } \\
\text { Lockwood }\end{array}$ & $\begin{array}{l}\text { What controls grasshopper } \\
\text { population size, density- } \\
\text { dependent or independent } \\
\text { factors? }\end{array}$ & $\begin{array}{l}\text { Community- } \\
\text { Landscape }\end{array}$ & $\begin{array}{l}\text { Grasshoppers, } \\
\text { precipitation and } \\
\text { temperature }\end{array}$ & Dryland & $\begin{array}{l}\text { Catastrophe } \\
\text { theory } \\
\text { Self-organized } \\
\text { criticality (1/f } \\
\text { noise) } \\
\text { Fractal analysis }\end{array}$ \\
\hline
\end{tabular}


conclude this special feature. The synthesis is organized around the topics of critical threshold conditions, system self-organization, scale and scaling laws, and threshold applications. We conclude that although a great deal has been learned about catastrophic thresholds in the past several decades, emphasis must now shift to linking nonequilibrial theory with application to demonstrate greater relevance and effectiveness of resiliencebased ecosystem management. This will require that the threshold concept be expanded beyond a heuristic conceptual model to organize and describe ecosystem behavior to include analytical protocols for anticipating, averting, and potentially reversing catastrophic change in ecosystems (Folke 2006).

Responses to this article can be read online at: http://www.ecologyandsociety.org/vol15/iss3/art38/ responses/

\section{Acknowledgments:}

Research was funded in part by a NSF Biocomplexity Project No. BCS-030846 to H. H. S. and to R.A.W. and a Faculty Development Grant from the Office of the Vice-Provost for Faculty Affairs, University of Virginia to R. A.W.

\section{LITERATURE CITED}

Allen, C. R., and C. S. Holling. 2010. Novelty, Adaptive Capacity, and Resilience. Ecology and Society 15(3):24 [online] URL: http://www.ecology andsociety.org/vol15/iss3/art24/).

Allen, T. F. H. and T. W. Hoekstra. 1992. Toward a unified ecology. Columbia University Press, New York, NY.

Archer, S. 1989. Have southern Texas savannas been converted to woodlands in recent history? American Naturalist 134(4):545-561.

Bak, P., C. Tang, and K. Wiesenfeld. 1987. Selforganized criticality: an explanation of $1 / \mathrm{f}$ noise. Physical Review Letters 59(4):381-384.

Beisner, B. E., D. T. Haydon, and K. Cuddington. 2003. Alternative stable states in ecology. Frontiers in Ecology and the Environment 1(7):376-382
Bestelmeyer, B. T., J. R. Brown, K. M. Havstad, R. Alexander, G. Chavez, and J. Herrick. 2003. Developing state-and-transition models for rangelands. Journal of Range Management 56(2):114-126.

Bohner, M. and A. Peterson. 2001. Dynamic equations on time scales: an introduction with applications. Birkhauser, Boston, Massachusetts, USA.

Briske, D. D., S. D. Fuhlendorf, and F. E. Smeins. 2005. State-and-transition models, thresholds, and rangeland health: a synthesis of ecological concepts and perspectives. Rangeland Ecology and Management 58(1):1-10.

Briske, D. D., S. D. Fuhlendorf and F. E. Smeins. 2006. A unified framework for assessment and application of ecological thresholds. Rangeland Ecology and Management 59(3):225-236.

Briske, D. D., R. A. Washington-Allen, C. Johnson, J. Lockwood, D. Lockwood, T. Stringham, and H.H. Shugart. 2010. Catastrophic thresholds: a synthesis of concepts, perspectives, and applications. Ecology and Society 15(3):37 [online] URL: http://www.ecologyandsociety.org/vol15/ iss3/art37/).

Folke, C. 2006. Resilience: the emergence of a perspective for social-ecological systems analysis. Global Environmental Change 16(3):253-267.

Garmestani, A. S., C. R. Allen, and L. H. Gunderson. 2009. Panarchy: discontinuities reveal similarities in the dynamic system structure of ecological and social systems. Ecology and Society 14(1): 15. [online] URL: http://www.ecologyandso ciety.org/vol14/iss1/art15/.

Gilmore, R. 1981. Catastrophe theory for scientist and engineers. Wiley, New York, New York, USA.

Groffman, P. M., J. S. Baron, T. Blett, A. J. Gold, I. Goodman, L. H. Gunderson, B. M. Levinson, M. A. Palmer, H. W. Paerl, G. D. Peterson, N. L. Poff, D. W. Rejeski, J. F. Reynolds, M. G. Turner, K. C. Weathers, and J. Wiens. 2006. Ecological thresholds: the key to successful environmental management or an important concept with no practical application? Ecosystems 9(1):1-13.

Gunderson, L. H. 2000. Ecological resilience-in theory and application. Annual Review of Ecology and Systematics 31:425-439. 
Habeeb, R. L., C. R. Johnson, S. Wotherspoon, and P. J. Mumby. 2007. Optimal scales to observe habitat dynamics: a coral reef example. Ecological Applications 17(3):641-647.

Habeeb, R. L., J. Trebilco, S. Wotherspoon, and C. R. Johnson. 2005. Determining natural scales of ecological systems. Ecological Monographs $\mathbf{7 5}$ (4):467-487.

Hilger, S. 1990. Analysis on measure chains-a unified approach to continuous and discrete calculus. Results in Mathematics 18(1):18-56.

Holling, C. S. 1973. Resilience and stability of ecological systems. Annual Review of Ecology and Systematics 4:1-23.

Jackson, R. B., and M. M. Caldwell. 1993. Geostatistical patterns of soil heterogeneity around individual perennial plants. Journal of Ecology $\mathbf{8 1}$ (4):683-692.

Johnson, C. R. 2009. Natural length scales of ecological systems: applications at community and ecosystem levels. Ecology and Society 14(1): 7. [online] URL: http://www.ecologyandsociety.org/voll4/ iss1/art7/.

Lockwood, D. R. and J. A. Lockwood. 2008. Grasshopper population ecology: catastrophe, criticality, and critique. Ecology and Society 13(1): 34. [online] URL: http://www.ecologyandsociety.org/ vol13/iss 1/art34/

Lockwood, J. A. and D. R. Lockwood. 1993. A unified paradigm of rangeland ecosystem dynamics through the application of catastrophe theory, Journal of Range Management 46(4):282-288.

Mayer, A. L. and M. Rietkerk. 2004. The dynamic regime concept for ecosystem management and restoration. BioScience 54(11):1013-1020.

Olsen, L. M., R. A. Washington-Allen, and V. H. Dale. 2005. Time-series analysis of land cover using landscape metrics. GIScience and Remote Sensing 42(5):200-223.

Pascual, M. and F. Guichard. 2005. Criticality and disturbance in spatial ecological systems. TRENDS in Ecology and Evolution 20(2):88-95.

Ridolfi, L., F. Laio, and P. D'Odorico. 2008.
Fertility island formation and evolution in dryland ecosystems. Ecology and Society 13(1): 5. [online] URL: http://www.ecologyandsociety.org/vol13/iss 1/ $\underline{\operatorname{art} 5 / .}$

Scheffer, M. 2009. Critical transitions in nature and society. Princeton University Press, Cambridge, UK.

Scheffer, M., J. Bascompte, W. A. Brock, V. Brovkin, S. R. Carpenter, V. Dakos, H. Held, E. H. van Nes, M. Rietkerk, and G. Sugihara. 2009. Early-warning signals for critical transitions. Nature 461(3):53-59

Scheffer, M. and S. R. Carpenter. 2003. Catastrophic regime shifts in ecosystems: linking theory to observation. Trends in Ecology and Evolution 18(12):648-656.

Scheffer, M., S. R. Carpenter, J. A. Foley, C. Folke, and B. Walker. 2001. Catastrophic shifts in ecosystems. Nature 413(6856):591-596.

Schlesinger, W. H., J. H. Reynolds, G. L. Cunningham, L. F. Huenneke, W. M. Jarrell, R. A. Virginia, and G. W. Whitford. 1990. Biological feedbacks in global desertification. Science $\mathbf{2 4 7}$ (4946):1043-1048.

Stringham, T. K., W. C. Krueger, and P.L.Shaver. 2003. State and transition modeling: a process based approach. Journal of Range Management 56 (2):106-113.

Thom, R. 1972. Structural stability and morphogenesis (English translation, D. H. Fowler, 1975). Addison Wesley, Reading, Massachusetts, USA.

Thomas D. M. and B. Urena. 2001. A mathematical model describing the evolution of West Nile-like encephalitis in New York City. Mathematical Computational Modelling $\mathbf{3 4}$ (7):771-781.

Thomas, D., M. Weedermann, L. Billings, J. Hoffacker, and R. A. Washington-Allen. 2009. When to spray: a time-scale calculus approach to controlling the impact of West Nile virus. Ecology and Society 14(2): 21. [online] URL: http://www.e cologyandsociety.org/vol14/iss2/art21/.

Wardwell, D. and C. R. Allen. 2009. Variability 
in population abundance is associated with thresholds between scaling regimes. Ecology and Society 14(2):42. [online] URL: http://www.ecology andsociety.org/vol14/iss2/art42/.

Washington-Allen, R. A., R. D. Ramsey, N. E. West, and R. A. Efroymson. 2006. A remote sensing-based protocol for assessing rangeland condition and trend. Rangeland Ecology and Management 59(1):19-29.

Washington-Allen, R. A., R. D. Ramsey, N. E. West, and B. E. Norton. 2008. Quantification of the ecological resilience of drylands using digital remote sensing. Ecology and Society 13(1): 33. [online] URL: http://www.ecologyandsociety.org/vol13/iss1/ art33/.

Washington-Allen, R. A., and L. F. Salo. 2007. Meeting review: catastrophic thresholds, perspectives, definitions, and applications. Bulletin of the Ecological Society of America 88(2):219-225. [online] URL: http://www.esajournals.org/doi/full/1 0.1890/0012-9623(2007)88\%5B219\%3ACTPDAA\% 5D2.0.CO\%3B2.

Washington-Allen, R. A., N. E. West, R. Douglas Ramsey, D. K. Phillips, and H. H. Shugart. 2009. Retrospective assessment of soil stability on a landscape subject to commercial grazing. Environmental Monitoring and Assessment: DOI 10.1007/ s10661-008-0661-3.

Westoby, M., B. H. Walker, and I. Noy-Meir. 1989. Opportunistic management for rangelands not at equilibrium. Journal of Range Management 42(4): 265-273. 